\title{
FAILURE OF PREHARVEST FOLIAGE SPRAYS WITH 2,4-D AND MALEIC HYDRAZIDE TO AFFECT THE SUCROSE CONTENT OF SUGARCANE
}

\author{
M. A. Lugo-López, G. Samuels, and R. Grant ${ }^{1}$
}

\section{INTRODUCTION}

Many substances have been synthesized recently which can induce profound alterations in the morphology and physiology of plants. Most of these are known as hormones or plant-growth regulators. The possibility of increasing the sucrose concentration of certain plants through the use of these substances has been given some consideration $(10)^{2}$.

In sugarcane, as well as in sugar beet production, one of the main goals of the farmer is to harvest a heavy tonnage to the acre with the highest possible sucrose concentration. Considerable progress has been made in obtaining reasonably large sugarcane crops through the use of better varieties, improved fertilizer practices, and adequate cultivation techniques. However, variations in sucrose concentration still elude practical control. This paper reports preliminary work conducted in Puerto Rico to test the effects of preharvest sprays of sugarcane with 2,4-D and maleic hydrazide on the final sucrose content of cane.

\section{REVIEW OF LITERATURE}

For the past two decades many plant-growth regulators or hormonelike substances have appeared on the market for agricultural use, mainly as weed killers. Among them 2,4-D has been most widely used. Attempts have recently been made to apply 2,4-D just prior to harvest as a regulator to induce the conversion of starches in the green-leaf section of the stalk and in the leaves into sucrose, with a consequent increase in the final sucrose accumulation of the millable cane.

Beauchamp (1) reported that, in Cuban plantations, increases in sucrose of 1.4 or 2.0 percent were obtained from dusting the cane foliage of P.O.J. 2878 and Media Luna $3 / 18$ with 4 to 6 ounces to the acre of the sodium salt of 2,4-D. The effects were more marked during the first 10 days fol-

${ }^{1}$ Associate Soil Scientist, Plant Physiologist, and former Research Assistant in Agronomy in charge of the Station Farm, respectively, Agricultural Experiment Station, University of Puerto Rico, Río Piedras, P. R. The authors wish to acknowledge the cooperation of A. R. Riera and J. Roldán, of the Station staff, during the establishment of the experiment at Colonia Rio Grande. Appreciation is also expressed to O. L. Heyn and R. Cuevas of the Eastern Sugar Associates for their encouragement and for providing facilities and labor for the field work.

${ }^{2}$ Numerals in parentheses refer to Literature Cited, p. 51. 
lowing treatment. Promising results have been reported from other areas also (3).

However, Loustalot, et al. (4), at Mayagüez, obtained no increases in the sucrose content of M. 336 by spraying the foliage with 0.2 -percent isopropyl ester of 2,4-D. Lugo-López and Grant failed to induce any significant differences in the sucrose content of P.O.J. 2878 by spraying with the sodium salt of 2,4-D at concentrations of 10,20 , and 30 pounds to the acre, at three intervals prior to harvest (5). In the last two cases mentioned the control plots produced about the same sucrose yields at harvesttime as the treated plots.

There have been also reports that indicate the 2,4-D applications may affect the sugar metabolism of other plants. Wort (14) from British Columbia reported increases in the total sugar content of buckwheat after treatment with small doses of the ammonium salt of 2,4-D within 1 day after the application.

Maleic hydrazide, one of the latest hormonelike substances to be described, has been found to have striking effects on plant growth, development, and flowering (8). Naylor and Davis (7) observed that corn plants sprayed with maleic hydrazide exuded droplets of sucrose and accumulated anthocyanin pigments. Quantitative sugar analysis indicated a thirteenfold increase in sugar concentration. Ririe and Mikkelson (11) obtained evidence that maleic hydrazide influences sugar beet growth and increased the sucrose content. Foliar sprays containing 0.3 and 0.025 percent made at the rate of 50 gallons per acre were applied, and the sucrose content was determined at three dates of harvest. An exudate appearing on barley after applications of maleic hydrazide was analyzed for sucrose by Currier et al. (2). Sucrose and starch were increased in cotton following application of maleic hydrazide (6). However, Stout (12) and Peto, et al. (9) reported no significant increases in the sucrose content of sugar beets when treated with maleic hydrazide. Wittwer and Hansen (13) reported that sprays with 0.25 -percent maleic hydrazide 30 to 40 days prior to harvest, or even as late as 3 or 5 days before harvest, considerably decreased the storage losses of sucrose in sugar beets.

\section{EXPERIMENTAL PROCEDURE}

Two fields were selected, one at the Station Farm at Río Piedras in the north and one at Colonia Río Grande of the Eastern Sugar Associates, near Central Santa Juana between Caguas and Gurabo, in east-central Puerto Rico. Both fields had been planted to P.O.J. 2878 and several ratoon crops harvested following the original plant cane. At Río Piedras the soil had been classified as a Vega Baja clay, a rather extensive, level, alluvial sugarcane soil of the north-coastal region. At Río Grande the soil was a 
Mabí clay occurring on long gentle slopes or nearly level areas throughout the humid sections, in association with the Juncos and Múcara soils derived from tuffaceous materials.

Both fields were divided into 6 blocks with 6 and 10 plots each at Río Piedras and Río Grande, respectively. The area of the plots was approximately 0.01 acre and they were nearly square. A row of cane was cut around each plot and two rows were left standing between each two plots to serve as buffer strips. There was approximately 20 feet between each two plots. The row of cane eliminated around each plot provided a very convenient pathway to facilitate spraying and sampling operations. The experimental design followed a randomized block layout with 6 and 10 treatments at Río Piedras and Río Grande, respectively, with 6 replications in each case. The treatments were as follows:

Río Piedras experiment: $0,2.5,5.0,7.5,10.0$, and 12.5 pounds to the acre of $2,4-\mathrm{D}$, acid basis.

Río Grande experiment: Control; 0.025, 0.05, 0.10, and 0.20 percent of 2,4-D, acid basis; and 0.025, 0.05, 0.10, 0.50 , and 2.00 percent of maleic hydrazide.

The 2,4-D was provided as the 97-percent sodium salt monohydrate, equivalent to 82-percent 2,4-dichlorophenoxyacetic acid. Maleic hydrazide (1,2-dihydropyridazine-3, 6-dione) formulated as a water-soluble diethanolamine salt, containing 30 percent of the active ingredient by weight as used. All dosages are expressed on the active-ingredient basis. Dreft at the rate of 0.05 percent was added to the sprays as a wetting agent and applications were made until run-off occurred on the cane leaves.

A common knapsack sprayer was used and the required amount of the salt was dissolved in 1 gallon of water which was enough to spray thoroughly the cane leaves in each plot. An extension was attached to the hose and the nozzle was tied to a bamboo pole 12 or 14 feet in length which could be raised well above the cane and allow the spray to fall on the cane foliage. The spraying operations were started at about 6:00 a.m. to avoid violent drafts and thus minimize the error in spraying. Samples of 10 canes each were obtained from each plot at random and taken to the Station mill at Río Piedras. After grinding, the juice was sampled and analyzed for Brix and polarization. The purity and available $96^{\circ}$ sugar percent cane were calculated from these data.

At Río Piedras samples were taken every day for 15 days following the treatments on April 14, 1951, and later every 5 to 7 days until all the cane was harvested at the end of 46 days. At Río Grande, samples were taken for 4 consecutive days after establishing the treatment differentials on February 26,1952 , and thereafter at intervals of 3 to 11 days, the sampling inter- 
vals being more extended towards the end of the experiment. The last sampling was made on May 9, 1952, some 72 days after the treatments were given.

\section{RESULTS AND DISCUSSION}

The Río Piedras experiment was designed primarily to continue the previous two experiments performed at Río Piedras and Humacao, reported

TABLE 1.-Daily fluctuations in available $96^{\circ}$ sugar yields of POJ 2878 cane sprayed with 2, 4-D prior to harvesting (Rio Piedras)

\begin{tabular}{|c|c|c|c|c|c|c|c|}
\hline \multirow{2}{*}{$\begin{array}{l}\text { Day of harvesting } \\
\text { after treatment }\end{array}$} & \multicolumn{6}{|c|}{$\begin{array}{l}\text { Available } 96^{\circ} \text { sugar when indicated pounds } \\
\text { of } 2,4-D \text { per acre were used }\end{array}$} & \multirow{2}{*}{ Means } \\
\hline & 0 & 2.5 & 5.0 & 7.5 & 10.0 & 12.5 & \\
\hline & Percent & Percent & Percent & Percent & Percent & Percent & Percent \\
\hline 1 & 14.2 & 14.9 & 14.2 & 13.6 & 14.9 & 13.9 & 14.3 \\
\hline 2 & 14.2 & 14.2 & 14.8 & 13.9 & 14.2 & 14.2 & 14.3 \\
\hline 3 & 14.2 & 13.8 & 14.3 & 14.2 & 14.3 & 13.5 & 14.1 \\
\hline 4 & 13.7 & 13.8 & 14.0 & 13.9 & 13.9 & 14.1 & 13.9 \\
\hline 5 & 14.1 & 14.1 & 14.1 & 14.3 & 14.3 & 13.4 & 14.1 \\
\hline 6 & 14.2 & 14.3 & 13.8 & 14.1 & 14.3 & 14.3 & 14.2 \\
\hline 7 & 14.2 & 14.7 & 14.6 & 13.7 & 14.1 & 14.3 & 14.3 \\
\hline 8 & 13.9 & 14.1 & 13.7 & 14.0 & 13.7 & 14.0 & 13.9 \\
\hline 9 & 14.2 & 13.9 & 13.9 & 14.4 & 14.1 & 14.3 & 14.1 \\
\hline 10 & 13.7 & 13.9 & 14.4 & 14.3 & 14.0 & 13.5 & 14.0 \\
\hline 11 & 14.9 & 13.9 & 13.9 & 14.7 & 14.3 & 14.5 & 14.4 \\
\hline 12 & 14.4 & 14.7 & 14.5 & 14.0 & 14.4 & 14.7 & 14.4 \\
\hline 13 & 14.4 & 14.1 & 13.8 & 13.4 & 14.4 & 14.0 & 14.0 \\
\hline 14 & 14.4 & - & 13.7 & - & 13.9 & 14.3 & 14.0 \\
\hline 15 & 14.3 & 14.8 & 14.4 & 13.3 & 13.8 & 14.4 & 14.2 \\
\hline 20 & 14.7 & 13.9 & 13.4 & 14.1 & 13.5 & 13.4 & 13.8 \\
\hline 25 & 14.4 & - & - & - & 13.5 & 12.9 & 13.6 \\
\hline 31 & 13.5 & 12.6 & - & - & 12.2 & 13.2 & 12.9 \\
\hline 38 & 13.3 & - & - & - & 12.1 & 12.4 & 12.6 \\
\hline 42 & 12.8 & - & - & - & 12.9 & 13.2 & 12.9 \\
\hline 46 & 12.8 & - & - & - & 11.5 & 12.1 & 12.1 \\
\hline Means of treatments. . & 14.0 & 14.1 & 14.0 & 14.0 & 13.7 & 13.7 & 13.9 \\
\hline
\end{tabular}

elsewhere (5). It was felt that the failure to affect the metabolism of the sugarcane plant favorably might be attributed, in part, to the extremely large doses of 2,4-D used in those experiments. In the next experiment at Río Piedras smaller quantities of 2,4-D were applied. The daily variations in Brix, polarization, purity, and available $96^{\circ}$ sugar percent cane were observed for 15 consecutive days, and thereafter every 5 to 7 days for more than $1 \frac{1}{2}$ months. Table 1 gives a summary of the sucrose yields obtained 
TABLE 2.-The sucrose percent cane yields of P.O.J. 2878 at various cutting intervals, as influenced by applications of $2,4-D$ and maleic hydrazide (Colonia Río Grande)

\begin{tabular}{|c|c|c|c|c|c|c|c|c|c|c|c|c|c|c|}
\hline \multirow{2}{*}{$\begin{array}{c}\text { Treat- } \\
\text { ment } \\
\text { No. }\end{array}$} & \multirow{2}{*}{ Treatment ${ }^{1}$} & \multicolumn{12}{|c|}{ Sucrose percent cane yields at dates of cutting indicated } & \multirow{2}{*}{ Mean } \\
\hline & & Feb. 27 & Feb. 28 & Feb. 29 & Mar. 1 & Mar. 4 & Mar. 12 & Mar. 18 & Mar. 27 & Apr. 7 & Apr. 17 & Apr. 28 & May 9 & \\
\hline 1 & Control & 10.23 & 10.30 & 10.34 & 10.61 & 9.85 & 10.82 & 10.47 & 10.05 & 11.76 & 10.33 & 11.98 & 11.71 & 10.70 \\
\hline 2 & 0.025 percent MH 30 & 11.20 & 10.38 & 10.19 & 9.99 & 10.19 & 10.58 & 10.80 & 10.34 & 11.52 & 11.70 & 11.86 & 12.20 & 10.91 \\
\hline 3 & .05 percent $\mathrm{MH} 30$ & 10.76 & 10.39 & 10.55 & 10.24 & 9.79 & 9.99 & 11.03 & 9.97 & 11.51 & 11.25 & 10.84 & 11.87 & 10.68 \\
\hline 4 & .10 percent MH 30 & 10.33 & 10.50 & 10.44 & 10.70 & 10.55 & 10.55 & 11.31 & 10.29 & 11.15 & 11.55 & 11.56 & 12.05 & 10.92 \\
\hline 5 & .50 percent $\mathrm{MH} 30$ & 10.61 & 10.46 & 10.65 & 10.46 & 10.60 & 10.43 & 9.79 & 10.32 & 11.08 & 11.38 & 11.66 & 11.66 & 10.76 \\
\hline 6 & 2.00 percent $\mathrm{MH} 30$ & 10.56 & 10.59 & 11.13 & 10.42 & 10.52 & 10.74 & 10.51 & 10.19 & 10.97 & 11.61 & 12.15 & 11.73 & 10.92 \\
\hline 7 & .025 percent $2,4-\mathrm{D}$ & 10.64 & 10.53 & 10.39 & 10.41 & 10.17 & 10.32 & 10.87 & 10.44 & 11.59 & 11.63 & 11.45 & 11.45 & 10.82 \\
\hline 8 & .05 percent $2,4-\mathrm{D}$ & 10.73 & 9.75 & 10.36 & 9.88 & 10.09 & 10.96 & 10.70 & 10.34 & 11.83 & 11.73 & 11.91 & 11.08 & 10.78 \\
\hline 9 & .10 percent $2,4-\mathrm{D}$ & 10.78 & 10.64 & 10.61 & 10.20 & 10.23 & 10.88 & 10.39 & 10.28 & 11.58 & 12.04 & 11.90 & 11.62 & 10.93 \\
\hline 10 & .20 percent $2,4-\mathrm{D}$ & 11.10 & 10.73 & 10.37 & 10.81 & 10.43 & 10.81 & 10.85 & 10.48 & 11.90 & 12.09 & 12.31 & 12.16 & 11.17 \\
\hline \multicolumn{2}{|c|}{ Mean of all treatments } & 10.70 & 10.43 & 10.50 & 10.39 & 10.24 & 10.60 & 10.67 & 10.27 & 11.49 & 11.53 & 11.76 & 11.75 & 10.86 \\
\hline \multicolumn{15}{|c|}{ Least significant difference needed for comparison at the: } \\
\hline \multirow{2}{*}{\multicolumn{2}{|c|}{$\begin{array}{l}5 \text {-percent level } \\
1 \text {-percent level }\end{array}$}} & 0.87 & 0.94 & 0.95 & 0.95 & 0.97 & 0.82 & 0.92 & 1.13 & 0.88 & 1.15 & 1.25 & 0.49 & \\
\hline & & 1.17 & 1.25 & 1.27 & 1.26 & 1.30 & 1.09 & 1.23 & 1.51 & 1.18 & 1.53 & 1.67 & .66 & \\
\hline
\end{tabular}

${ }^{1} \mathrm{MH}=$ Maleic hydrazide. 
for the period. No significant differences were observed between the means of the various treatments.

The Río Grande experiment was designed to test still smaller doses of $2,4-\mathrm{D}$ and included maleic hydrazide treatments. Table 2 shows the yields of available $96^{\circ}$ sugar percent cane at various intervals for P.O.J. 2878

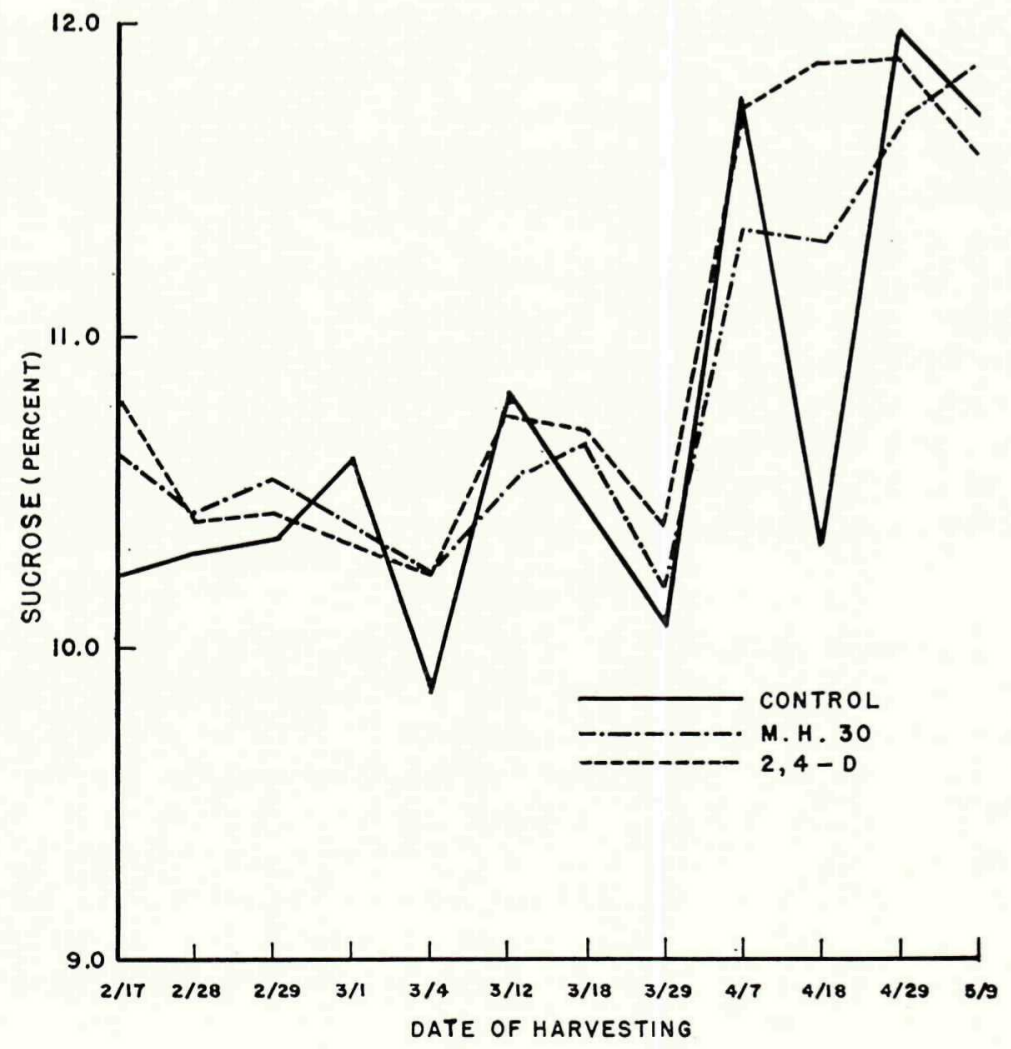

Fig. 1.-Mean results of the combined 2,4-D and the combined maleic hydrazide treatments, and of the controls, showing percentage of sucrose at various harvesting dates.

treated with 2,4-D and maleic hydrazide. There were no significant differences between the means of the treatments. The yields from the plots receiving a 0.20 -percent solution of 2,4-D were quite consistently higher throughout the harvesting season than those from the check plots, but the differences were not significant even at the 5-percent level. The mean results of the combined 2,4-D and the combined maleic hydrazide treatments, as well as of the controls, are shown graphically in figure 1 . 
There were some definite high and low sucrose levels during the harvesting season, and particularly towards the end of it, the canes from the treated plots seemed able to retain their sucrose accumulation while the sucrose yields of the check plots reached a very low level.

A general inspection of the data indicates that the daily variations in sucrose content throughout the harvesting season were attributable rather to weather conditions than to treatments. There is no doubt that weather variations have a pronounced effect on the final sucrose accumulation of cane at harvesttime. Furthermore, there are also indications that each cane variety has an optimum period during which its sucrose accumulation reaches a peak. Both of these factors will be considered in detail in forthcoming reports.

The use of plant-growth regulators in an effort to affect the ripening of the green-leaf millable stalks of cane at harvesttime should not be attempted yet by sugarcane growers in light of the results obtained in these experiments. The evidence from experimental data in Puerto Rico is rather discouraging. However, the physiologic basis for expecting favorable metabolic changes from preharvest sprays with growth regulators is sound, but further work must be undertaken before advancing any definite conclusions.

\section{SUMMARY}

Data are presented here on the effect of applications of 2,4-D and maleic hydrazide to sugarcane at intervals prior to harvesttime. Field experiments were conducted at Río Piedras in northern Puerto Rico and at Colonia Río Grande, between Caguas and Gurabo, in east-central Puerto Rico. Daily fluctuations in Brix, polarization, purity, and available $96^{\circ}$ sugar percent cane were followed for 46 - and 72 -day periods, respectively. No significant differences were observed between the mean available $96^{\circ}$ sugar percent cane that could be ascribed to treatments. Seasonal variations and variations attributable to weather conditions were rather important factors at both locations.

\section{RESUMEN}

Se presentan aquí datos sobre el efecto de aplicaciones de 2,4-D y "maleic hydrazide" a intervalos previos a la recolección de la caña. Se establecieron experimentos de campo en Río Piedras, al norte de Puerto Rico, y en la Colonia Río Grande, entre Caguas y Gurabo, en la zona este-central de la Isla. Se estudiaron las fluctuaciones en Brix, polarización, pureza y sacarosa durante períodos de 46 y 72 días, respectivamente. No se registraron diferencias significativas debido al efecto de los tratamientos, entre los valores promedio de sacarosa, en ninguna de las dos localidades. Se ob- 
servaron variaciones muy marcadas en ambas localidades debidas a la época de corte de las muestras.

\section{LITERATURE CITED}

1. Beauchamp, C. E., Effects of 2,4-D on sugar content of sugarcane, Sugar $J .13$ (5) 57-70, Oct. $1950 ; 13(6)$ 20-30, Nov. 1950.

2. Currier, H. B., Day, B. E. and Crafts, A. S., Some effects of maleic hydrazide on plants, Bot. Gaz.112(3) 272-80 1951.

3. De Oliveira, B. D., et al., Expeirmentos para aumentar o teor em sacarose da cana de azúcar, Report of the Brazilian observers on the experiments of Dr. C. E. Beauchamp, Brazil Azucareiro 37(4) 92-6 1951.

4. Loustalot, A., Cruzado, H. J. and Muzik, T. J., The effect of 2,4-D on the sugar content of sugarcane, Sugar J. 13(5) 781950.

5. Lugo-López, M. A. and Grant, R., Preharvest foliage sprays of sugarcane with 2,4-D, J. Agric. Univ. P. R. 36(3) 187-93 1952.

6. McIlrath, W. J., Response of the cotton plant to maleic hydrazide, Am. J. Bot. 37 816-19, 1950.

7. Naylor, A. W. and Davis, E. A., Some effects of maleic hydrazide on growth and respiration of representative monocots and dicots, Proc. Am. Soc. Plant Physiol. (24th meeting), abstracts p. 13, Dec. 1949.

8. Naylor, A. W. and Davis, E. A., Maleic hydrazide as a plant growth inhibitor, Bot. Gaz. 112(1) 112-26 1950.

9. Peto, F. H., et al., Effects of preharvest sprays of maleic hydrazide on sugar beets, , Am. Soc. Sugar Beet Tech., abstracts p. 4, Salt Lake City, Feb. 1952.

10. Pipes, F., Hormones to increase yield, edit., Sugar J. 12 (8) 31950.

11. Ririe, D. and Mikkelson, D. S., The effect of maleic hydrazide on sugar beet growth and sucrose content in certain field experiments, Am. Soc. Sugar Beet Tech., abstracts p. 3, Salt Lake City, Feb. 1952.

12. Stout, M., Two years results evaluating effect of preharvest sprays of maleic hydrazide on respiration and spoilage of sugar beets, Am. Soc. Sugar Beet Tech., abstracts p. 4, Salt Lake City, Feb. 1952.

13. Wittwer, S. H. and Hansen, C.M., Progress report on the effects of preharvest foliage sprays of maleic hydrazide on storage losses of sugar beets, paper presented at meeting of Am. Soc. of Sugar Beet Tech., Detroit, Jan. 25, 1951.

14. Wort, D. J., Effect of nonlethal concentrations of 2,4-D on buckwheat, Plant Physiol. 26(1) 50-7 1950. 